\title{
GAMBARAN FAKTOR RISIKO PADA IBU DENGAN BAYI LAHIR MATI (STILLBIRTH) DI KABUPATEN TASIKMALAYA TAHUN 2017
}

\author{
Annisa Mahardika, ${ }^{1}$ Widya Maya Ningrum ${ }^{2}$ \\ Prodi D III Kebidanan, Fakultas Ilmu Kesehatan, Universitas Galuh, Indonesia \\ Corresponding Email: widyamayaningrum@gmail.com \\ (Diterima 25-11-2019; disetujui 18-11-2019; dipublish 26-11-2019)
}

\begin{abstract}
Abstrak
Stillbirth merupakan keadaan bila kematian bayi terjadi sebelum lahir, tetapi setelah kehamilan 20 minggu atau lebih dan kematian bayi tersebut masih di dalam rahim. Data di Kabupaten Tasikmalaya, angka kejadian stillbirth pada 2017 sebanyak 187 kasus (0.61\%). Tujuan penelitian ini adalah untuk mengetahui gambaran faktor risiko bayi lahir mati (stillbirth) dari faktor ibu dan penyulit kehamilan. Penelitian ini bermanfaat bagi ibu dapat menambah wawasan dan pengetahuan bagi ibu hamil tentang faktor - faktor penyebab bayi baik lahir mati dari faktor ibu. Jenis penelitian ini adalah kuantitatif dengan metode deskriptif. Populasi dalam penelitian ini ibu yang mengalami bayi lahir mati sebanyak 187 kasus. Kemudian data dikumpulkan menggunakan data skunder diperoleh ari buku KIA dan otopsi verbal kemudian dianalisis secara naratif. Hasil penelitian menunjukkan bahwa usia ibu yang melahirkan bayi lahir mati (Stillbirth) sebagian besar adalah sesuai 20-35 tahun (68.4\%), Paritas ibu yang melahirkan bayi lahir mati (Stillbirth) sebagian besar adalah paritas multipara $(72.7 \%)$ dan penyulit kehamilan sebagian besar adalah preeklampsia (18.2\%), KPD sebanyak 24 orang (12.8\%), anemia sebanyak 14 orang $(7.5 \%)$, serotinus sebanyak 3 orang (1.6\%), perdarahan antepartum 6 orang (3.2\%). Kesimpulan dari penelitian ini adalah faktor risiko pada ibu terjadinya stillbirth usia 20-35 tahun, paritas multipara dan penyulit kehamilan preeklampsia. Oleh karena itu sebaiknya bidan melakukan deteksi dini pada ibu hamil beresiko tinggi dan komplikasi yang terjadi pada kehamilan. Selain itu bidan dapat memberikan pendidikan kesehatan tentang penyulit kehamilan.
\end{abstract}

\begin{abstract}
Stillbirth is a condition when infant mortality occurs before birth, but after 20 weeks of pregnancy or more and the baby's death is still in the womb. Data in Tasikmalaya Regency, the number of stillbirth events in 2017 was 187 cases (0.61\%). The purpose of this study was to determine the description of risk factors for stillbirths from maternal factors and complications of pregnancy. This research is useful for mothers can increase insight and knowledge for pregnant women about factors - factors causing good baby stillbirth from mother factor. This research type is quantitative with descriptive method. The population in this study of mothers who have stillborn infants as many as 187 cases. Then data collected using secondary data obtained from KIA book and verbal autopsy then analyzed in narrative.The results showed that the age of mothers who gave birth to stillbirth were mostly 20-35 years old (68.4\%), the parity of the mother who delivered the stillbirth was mostly multiparous parity $(72.2 \%)$ and partial complication of pregnancy (18.2\%), KPD counted 24 people (12.8\%), anemia as many as 14 people $(7.5 \%)$, serotonin as many as 3 people (1.6\%), antepartum hemorrhage 6 people $(3.2 \%)$. The conclusions of this study were risk factors in maternal age of stillbirth 20-35 years, multiparous parity and preeclampsia pregnancy complication. Therefore midwives should do early detection in pregnant women at high risk and complications that occur in pregnancy. In addition, midwives can provide health education about pregnancy complications.
\end{abstract}

Keywords: Age, parity, complication, stillbirth 


\section{PENDAHULUAN}

Kesehatan merupakan suatu keadaan dimana kesejahteraan masyarakat yang dinilai pada tingginya angka kesakitan dan kematian. Angka Kematian Bayi (AKB) dan Angka Harapan Hidup Waktu Lahir (AHH) telah ditetapkan sebagai indikator derajat kesehatan. Kematian bayi adalah kematian anak kurang dari satu tahun per 1000 kelahiran hidup. Kematian bayi bisa terjadi pada saat kehamilan kurang dari 20 minggu. Bayi yang dilahirkan mati disebut dengan stillbirth (lahir mati) ${ }^{1}$.

Data Stillbirth berdasarkan World Health Organization (WHO) tahun 2011 melaporkan bahwa setiap hari lebih dari 7.200 bayi lahir mati. Sebagian besar di antaranya terjadi di negara berpendapatan rendah hingga sedang (98 persen) (VOA Indonesia, 2011). Di Indonesia data stillbirth termasuk pada kematian neonatal dimana kematian tersebut mencapai $32 / 1000$ kelahiran hidup, hal ini menunjukan bahwa derajat kesehatan negara kita masih rendah. Jawa Barat melaporkan data stillbirth yaitu sebesar 3,097 kematian dari 935,003 kelahiran $(0,33 \%)^{2}$.

Stillbirth merupakan keadaan bila kematian bayi terjadi sebelum lahir, tetapi setelah kehamilan 20 minggu atau lebih. Kebanyakan kematian sewaktu bayi masih di dalam rahim (Smith AM, 2017). Salah satu faktor risiko terjadinya stillbirth adalah faktor ibu. Faktor ibu yang menjadi risiko terjadinya stillbirth adalah usia, indeks masa tubuh, deprivasi sosial, masalah plasenta, gangguan pada ibu (preeklamsi, infeksi), kehamilan lewat waktu, kehamilan kembar, dan isoimunisasi ${ }^{3}$.

Sejalan dengan pernyataan Chapman, menurut Noor Latifah A dalam penelitiannya dengan judul "Hubungan Frekuensi Kunjungan ANC Selama Kehamilan Dengan Kejadian Kematian Neonatal Tahun 2012, menyatakan bahwa beberapa faktor penyebab bayi lahir mati diantaranya adalah usia ibu terlalu muda atau terlalu tua, riwayat penyakit, paritas yang terlalu banyak, adanya penyulit selama kehamilan, dan komplikasi kehamilan ${ }^{4}$. Hal ini didukung oleh penelitian yang dilakukan oleh Djaja (2009) dalam penelitiannya mengenai Tren Lahir mati dan Kematian Neonatal di Indonesia hasil Survei Kesehatan tahun 1995-2007 menemukan bahwa penyebab bayi lahir mati diantaranya KPD (23\%), paritas lebih dari satu (6.9\%), hipertensi selama kehamilan (23.6\%).

Berdasarkan penelusuran data di Kabupaten Tasikmalaya, angka kejadian bayi lahir mati pada tahun 2016 sebanyak 213 kasus $(0.68 \%)$ dari 31.199 kelahiran, sedangkan pada 2017 sebanyak 187 kasus $(0.608 \%)$ dari 30.753 kelahiran, melihat dari data tersebut kasus bayi lahir mati mengalami penurunan bila dibandingkan dengan tahun sebelumnya. Namun demikian kasus bayi lahir mati masih menjadi permasalahan yang perlu diteliti lebih lanjut, khususnya faktor risiko pada ibu yang dapat menyebabkan bayi lahir mati. Penelitian ini bertujuan untuk mengetahui gambaran faktor risiko ibu dengan bayi lahir mati (Stillbirth) di Kabupaten Tasikmalaya tahun 2017.

\section{METODE PENELITIAN}

Jenis penelitian ini adalah kuantitatif dengan metode deskriptif yaitu untuk menggambarkan faktor risiko ibu dengan bayi lahir Mati (Stillbirth) di Kabupaten Tasikmalaya 2017. Populasi dalam penelitian ini adalah ibu yang mengalami bayi lahir mati pada tahun 2017 , dan teknik pengambilan sampel menggunakan total sampling yaitu seluruh populasi yang berjumlah 187 ibu yang mengalami stillbirth

Pengambilan data kasus stillbirth dalam penelitian ini dilakukan di satu tempat, dimana sebelumnya peneliti melakukan koordinasi dan kerja sama dengan pihak Dinas kesehatan untuk menginformasikan kepada semua bidan koodrinator tiap Puskesmas untuk mengumpulkan partograf buku KIA dan otopsi verbal kasus bayi lahir mati. Peneliti dengan pihak dinas kesehatan melakukan kontrak waktu dan 
tempat pengambilan data tersebut yakni di Hotel Horison pada tanggal 30 Mei 2018.

Instrumen yang digunakan dalam melakukan penelitian ini berupa format isian untuk merekap data-data yang sudah tersedia dalam buku KIA dan Otopsi verbal dari bidan di tiap Puskesmas. Selanjutnya data terkumpul dianalisis dengan univariabel dan disajikan dalam bentuk tabel distribusi fekuensi

\section{HASIL PENELITIAN DAN}

\section{PEMBAHASAN}

1. Usia ibu yang melahirkan bayi lahir mati (Stillbirth)

Tabel 1 Distribusi frekuensi Usia ibu yang melahirkan bayi lahir mati (Stillbirth)

\begin{tabular}{lcc}
\hline Umur & Frekuensi & Persentase \\
\hline $\begin{array}{l}<20 \\
\text { tahun }\end{array}$ & 15 & 8.0 \\
$20-35$ & 128 & 68.4 \\
tahun & & \\
$>35$ & 44 & 23.5 \\
tahun & & \\
\hline Jumah & 187 & 100.0 \\
\hline
\end{tabular}

Usia ibu yang melahirkan bayi lahir mati (Stillbirth) sebagian besar berusia antara 20-35 tahun yaitu sebanyak 128 orang $(68.4 \%)$, dan paling seidkit berusia < 20 tahun yaitu 15orang $(8.0 \%)$.

2. Paritas ibu yang melahirkan bayi lahir mati (Stillbirth)

Tabel 2 Distribusi frekuensi paritas ibu yang melahirkan bayi lahir mati (Stillbirth)

\begin{tabular}{lcc}
\hline \multicolumn{1}{c}{ Paritas } & Frekuensi & Persentase \\
\hline Primipara & 43 & 23.0 \\
Multipara & 136 & 72.7 \\
Grandepara & 8 & 4.3 \\
\hline Jumah & 187 & 100.0 \\
\hline
\end{tabular}

Paritas ibu yang melahirkan bayi lahir mati (Stillbirth) sebagian besar adalah multipara yaitu sebanyak 136 orang $(72.7 \%)$ dan paling sedikit sebagai paritas grandepara sebanyak 8 orang
(4.3\%). Adapun jarak kehamilan yang didasarkan dari jumlah anak tersebut dapat dilihat pada tabel berikut:

3. Penyulit kehamilan pada ibu yang melahirkan bayi lahir mati (Stillbirth)

Tabel 4 Distribusi frekuensi penyulit kehamilan pada ibu yang melahirkan bayi lahir mati (Stillbirth)

\begin{tabular}{lcc}
\hline Penyulit & $\begin{array}{c}\text { Frekuen } \\
\text { si }\end{array}$ & $\begin{array}{c}\text { Persentas } \\
\text { e }\end{array}$ \\
\hline Anemia & 14 & 7.5 \\
Preeklams & 34 & 18.2 \\
ia & & \\
Perdaraha & 6 & 3.2 \\
$\mathrm{n}$ & & \\
antepartu & & \\
m & & \\
KPD & 24 & 12.8 \\
Serotinus & 3 & 1.6 \\
Tidak ada & 106 & 56.7 \\
\hline Jumah & 187 & 100.0 \\
\hline
\end{tabular}

Data pada tabel 5.7 menunjukkan bahwa penyulit kehamilan pada ibu yang melahirkan bayi lahir mati (Stillbirth) sebagian besar preeklampsia sebanyak 34 orang (18.2\%), KPD sebanyak 24 orang (12.8\%), anemia sebanyak 14 orang $(7.5 \%)$, serotinus sebanyak 3 orang (1.6\%), perdarahan antepartum 6 orang (3.2\%). Sedangkan ibu yang tidak mengalami penyulit kehamilan sebanyak 97 orang (61.9\%).

\section{PEMBAHASAN}

1. Usia ibu yang melahirkan bayi lahir mati (Stillbirth)

Hasil penelitian ini didapatkan bahwa usia ibu yang melahirkan bayi lahir mati (Stillbirth) sebagian besar berusia antara 20-35 tahun. Melihat dari data tersebut mengindikasikan bahwa sebagian besar responden melahirkan pada usia resiko rendah. Ibu yang melahirkan bayi lahir mati pada usia tersebut dapat disebabkan adanya komplikasi atau penyulit kehamilan, persalinan maupun pada janin itu sendiri. Padahal menurut 
Siswosudarmo (2010) kurun reproduksi sehat adalah antara umur 20-35 tahun. Ini berarti bahwa umur ibu di luar batas tersebut merupakan kehamilan dengan risiko tinggi/ Kehamilan di usia lebih dari 35 tahun mengandung beberapa risiko yang meningkat pada ibu yang mengalami hipertensi dan pre eklampsia maupun pada janin.

Data lain ditemukan adanya usia responden yang < 20 tahun atau $>35$ tahun. Menurut analisis penulis usia ibu berisiko dapat menjadi faktor risiko untuk kejadian Stillbirth, bahkan setelah usia tua dan memperhitungkan kondisi medis yang sebenarnya lebih berisiko terjadi di pada usia yang lebih tua ( $>40$ tahun). Sebelum diagnosis kondisi kesehatan, wanita yang lebih tua berisiko akan Stillbirth hal ini berkaitan dengan dengan anomali bawaan. Hasil penelitiannya menunjukkan, salah satu faktor Stillbirth secara statistik lebih sering terjadi pada wanita yang berusia lebih tua dan umumnya stillbirth terjadi usia kehamilan trimetser III (Fretts, 2007).

Hasil penelitian ini sesuai dengan penelitian Nababan dalam penelitiannya pada tahun 2007 mengenai gambaran faktor yang menyebabkan terjadinya kematian janin Di RSU dr. Pirngadi Medan Tahun 2007 menemukan bahwa umur ibu dengan kasus kematian janin dalam kandungan berumur 20-35 tahun $(46,8 \%)$.

Berdasarkan uraian tersebut peulis berpendapat bahwa usia ibu berisiko dapat menjadi faktor risiko untuk kejadian Stillbirth, bahkan setelah usia tua dan memperhitungkan kondisi medis yang sebenarnya lebih berisiko terjadi di pada usia yang lebih tua. Sedangkan wanita yang terlalu muda seringkali secara emosional dan fisik belum matang. Baik usia tua maupun terlalu muda memiliki resiko untuk mengalami komplikasi kehamilan.

2. Paritas ibu yang melahirkan bayi lahir mati (Stillbirth)
Berdasarkan hasil penelitian didapatkan bahwa paritas ibu yang melahirkan bayi lahir mati (Stillbirth) sebagian besar adalah multipara yaitu sebanyak 109 orang (58.3\%). Melihat dari data tersebut dapat mengindikasikan bahwa jumlah kasus stillbirth lebih banyak terjadi pada paritas multipara, dalam hal ini dapat terjdinya jarak kehamilan yang terlalu dekat.

Secara teori jumlah kehamilan merupakan jumlah bayi yang dilahirkan oleh ibu baik dalam keadaan hidup maupun meninggal. Jumlah anak yang dilahirkan tersebut dapat menggambarkan kondisi kesehatan ibu maupun janin (Benson, 2009).

Nababan dalam penelitiannya pada tahun 2007 mengenai gambaran Faktor Yang Menyebabkan Terjadinya Kematian Janin Dalam Kandungan Di RSU dr. Pirngadi Medan Tahun 2007 dalam penelitiannya penderita IUFD sebelumnya tidak mengalami riwayat pada kehamilan sebelumnya, dari penelitian ditemukkan riwayat kehamilan tidak ada hubungan dengan kejadian IUFD.

Menurut analisis penulis jumlah anak atau paritas berkaitan pula dengan riwayat kehamilan sebelumnya. Apabila ibu mempunya riwayat janin meninggal sebelumnya maka hal tersebut meningkatkan risiko kematian janin dalam rahim terulang kembali, oleh sebab itu ibu hamil sebaiknya menjaga aktivitas dan jangan berlebihan.

3. Penyulit kehamilan pada ibu yang melahirkan bayi lahir mati (Stillbirth)

Hasil peneltian ini dapatkan bahwa bahwa penyulit kehamilan pada ibu yang melahirkan bayi lahir mati (Stillbirth) sebagian besar preeklampsia. Melihat dari data tersebut menginsikasikan bahwa salah satu peyulit kehamilan yang dapat menyebabkan bayi lahri mati adalah karena tekanan darah tinggi. 
Pada umur <20 tahun secara fisik kondisi rahim dan panggul belum berkembang optimal, sehingga dapat mengakibatkan resiko kesakitan dan kematian pada kehamilan dan dapat menyebabkan pertumbuhan serta perkembangan fisik ibu terhambat. Pada umur > 35 tahun mengalami pre eklamsia disebabkan karena peningkatan umur berpengaruh dalam peningkatan darah karena menurunnya fungsi organ tubuh.

Dalam penelitiannya menemukan bahwa ada pengaruh hubungan antara kejadian PEB dengan faktor gravida, distensi rahim, riwayat penyakit penyerta, usia ibu dan paritas pada pasien rawat inap di ruang ICU RSUD Dr. Moewardi Surakarta. Kemudian penelitian Wardani (2010) menemukan bahwa sebagian besar $160(71,1 \%)$ ibu hamil berusia 20-35 tahun dan sebagian besar $152 \quad(67,6 \%)$ ibu hamil merupakan multigravida. Hasil uji ChiSquare didapatkan ada hubungan antara usia dan gravida dengan kejadian preeklampsia $(\mathrm{p}<0,05)^{6}$.

Data lain ditemukan komplikasi atau penyulit kehamilan kedua terbanyak adalah KPD. Beberapa penulis mendefinisikan KPD yaitu apabila ketuban pecah spontan dan tidak diikuti tanda-tanda persalinan, ada teori yang menghitung beberapa jam sebelum inpartu, misalnya 1 jam atau 8 jam sebelum inpartu. Ada juga yang menyatakan dalam ukuran pembukaan servik pada kala I, misalnya ketuban pecah sebelum pembukaan servik pada primigravida $3 \mathrm{~cm}$ dan pada multigravida kurang dari $5 \mathrm{~cm}$. Ketuban pecah dini adalah pecahnya ketuban sebelum terdapat tanda persalinan mulai dan ditunggu satu jam belum terjadi inpartu. Sebagian besar ketuban pecah dini adalah hamil aterm diatas 37 minggu, sedangkan 36 minggu tidak terlalu banyak ${ }^{7}$.

Kemudian komplikasi lain adalah anemia sebanyak 14 orang (7.5\%), menurut Manuaba (2010) anemia dalam kehamilan adalah kadar hemoglobinnya kurang dari $11 \mathrm{gr} / \mathrm{dl}$. Anemia pada trimester kedua saat kadar hemoglobinnya kurang dari $11 \mathrm{gr} / \mathrm{dl}$ dan anemia pada trimester satu dan ketiga saat kadar hemoglobinnya kurang dari 10,5 gr/dl (Manuaba, 2010).

Kekurangan oksigen pada tali pusat dapat menghambat pada pertumbuhan dan perkembagan janin, tidak adekuatnya aliran darah ke jaringan akibat kurangnya hemoglobin dapat mengakibatkan kematian Anemia pada kehamilan menyebabkan kurangnya suplai nutrisi dan oksigen pada placenta yang akan berpengaruh pada fungsi placenta terhadap janin ${ }^{8}$.

Penyulit lainnya adalah serotinus sebanyak,kehamilan serotinus merupak an kehamilan yang berlangsung selama 42 minggu atau lebih sejak awal periode haid yang diikuti oleh ovulasi 2 minggu kemudian. Meskipun kehamilan serotinus ini mungkin mencakup 10 persen dari seluruh kehamilan, sebagian di antaranya mungkin tidak benar-benar serotinus, tetapi lebih disebabkan oleh kekeliruan dalam memperkirakan usia gestasional. Sekali lagi nilai informasi yang tepat mengenai lama kehamilan cukup jelas, karena pada umumnya semakin lama janin yang benar-benar serotinus itu berada didalam rahim, semakin besar pula resiko bagi janin dan bayi baru lahir untuk mengalami gangguan yang berat ${ }^{8}$.

Penyebab stillbirth dari akibat kehamilan adalah perdarahan antepartum ${ }^{9}$. Perdarahan antepartum yang berbahaya umumnya bersumber pada kelainan plasenta ${ }^{10}$, umpamanya kelainan servik tidak seberapa bahaya. Pada setiap perdarahan antepartum pertama-tama harus selalu dipikirkan bahwa hal itu bersumber pada kelainan plasenta sehingga menimbulkan pertumbuhan janin terhambat ${ }^{11,12}$.

\section{SIMPULAN DAN SARAN}

Usia ibu yang melahirkan bayi lahir mati (Stillbirth) di Kabupaten Tasikmalaya tahun 2017 sebagian besar adalah suai 20-35 tahun.Paritas ibu yang melahirkan bayi 
lahir mati (Stillbirth) di Kabupaten Tasikmalaya tahun 2017 sebagian besar adalah paritas multipara. Penyulit kehamilan pada ibu yang melahirkan bayi lahir mati (Stillbirth) di Kabupaten Tasikmalaya tahun 2017 sebagian besar adalah preeklampsia. Sebaiknya ibu hamil dapat merencakan kehamilan dengan melihat dari usia, paritas dan jarak kehamilan dengan menggunakan alat kontrasepsi jangka panjang seerti AKDR atau implant supaya antara kehamilan ke satu dan kehamilan berikutnya terdapat jarak yang ideal.

\section{DAFTAR PUSTAKA}

1. Chuwa, Francisca S. 2017. Maternal and fetal risk factors for stillbirth in Northern Tanzania: A registry-based retrospective cohort study. PLoS ONE. 10.1371/journal.pone.0182250

2. Arikunto, 2010. Prosedur Penelitian, Suatu Pendekatan Praktek;Edisi Revisi PT. Asdi Mahasatya

3. Benson, Ralph. 2009. Buku Saku Obstetri dan Ginekologi. EGC. Jakarta

4. Chapman Vicky, 2013. Persalinan Dan Kelahiran Asuhan Kebidanan. Jakarta : EGC
5. Choiroel A (2005) Hubungan kualitas pemeriksaan antenatal dengan kematian perinatal di Kabupaten Banyumas.http://www.eprints.undip.a c.id/4445/

6. Dinas Kesehatan Kabupaten Tasikmalaya. Profil Tahunan Kabupaten Tasikmalaya

7. Dorr. 2015) Changes in cerebral hemodynamics and oxygenation in the first 24 hours after birth asphyxia. Pediatrics; 92:365-72.

8. Djaja (2009) Tren Lahir mati dan Kematian Neonatal di Indonesia hasil Survei Kesehatan tahun 1995-2007.

9. Freeman, 2005. The Significance of a previous stillbirth.American Journal of Obstetrics and Gynecology. https://doi.org/10.1016/00029378(85)90414-4

10. Fretts. 2007 Stillbirth :Common Causes and Prevention.

11. Gardosi, Jason, et. All (2013) . Maternal and fetal risk factors for stillbirth: population based study. BMJ (Clinical research ed.) http://www.pubmedcentral.nih.gov/arti clerender.fcgi?artid=

12. Indrawati, 2010. Panduan Perawatan Kehamilan. ISBN. 7981-602-97064-13 Jogjakarta. Atma Media Press 